\title{
Respira fundo e prende: um pequeno railo-X da ecodistopia no cinema brasileiro, do regime militar aos militares no regime
}

\author{
Take a deep breath and hold it in: a brief X-ray of eco-dystopia in Brazilian cinema, \\ from the military regime to the current militarized administration
}

\author{
Alfredo Suppia \\ Professor e pesquisador de cinema e audiovisual. Departamento de Cinema, Unicamp.
}

\section{RESUMO}

O conflito (ou contraponto) entre a modernidade e a natureza sempre teve um papel de destaque na literatura brasileira de ficção científica (FC). A partir do final da década de 1960, esse conflito se intensifica em especulações cinematográficas sobre o futuro do Brasil e do mundo diante de catástrofes ambientais possíveis. Nesse período, ao longo das décadas de 70 e 80, o debate ecológico em alguns filmes brasileiros, frente à polêmica política nacional sobre questões ambientais, tornou-se uma via de acesso efetiva em termos de crítica ao regime ditatorial - e também uma maneira de se evitar a censura, aproveitando-se de códigos de gênero e de uma agenda mundial para se protestar contra um governo militar autoritário. Mas a ecodistopia no cinema brasileiro não se limitou ao período da ditadura, e hoje parece ter seu interesse reavivado, seja pela aparição de curtas e longas com temática direta ou indiretamente ambientalista, seja pelo retorno do ambientalismo como bandeira de resistência contra o governo de extrema direita que assumiu o poder em 2019. 0 objetivo deste artigo é apresentar e discutir alguns exemplos da ecodistopia no cinema brasileiro, uma manifestação quase sempre associada ao gênero FC.

PALAVRAS-CHAVE: Cinema brasileiro; ecodistopia; ambientalismo.

\section{ABSTRACT}

The conflict between modernity and nature has always played a role in Brazilian science fiction (SF) literature. Since the end of the 1960s, this conflict also appears in cinematic speculations about the future of Brazil and the world in light of possible environmental catastrophes. During this period, throughout the 70s and 80s, films addressing environmental 
issues appeared to be instrumental in terms of critiquing the dictatorship. Genre films like SF or eco-dystopias were also a way to avoid censorship, taking advantage of a global agenda to protest the military rule. But eco-dystopia in Brazilian cinema has not gone away with the dictatorship. Today, the Brazilian eco-dystopian film seems to gain a new momentum. Environmentalist motifs have been appearing frequently in shorts and feature-films, and environmentalism in Brazil is once again a matter of resistance against the extreme right that came to power in 2019. The aim of this article is to present and discuss some examples of ecodystopia in Brazilian cinema.

KEYWORDS: Brazilian cinema; ecodistopia; environmentalism.

\section{Introdução}

No artigo "Science Fiction and Ecology", Brian Stableford (2007, p. 128) nos lembra que o termo ecologia foi cunhado por Ernst Haeckel em 1873, mas não se estabeleceu como uma disciplina formal antes do final da década de 1920, na esteira do primeiro trabalho notável sobre a questão ambiental: Animal Ecology (1927), de Charles Elton, e seu conceito de "Eltonian pyramid". Pouco depois, ainda segundo Stableford, uma preocupação ecológica começava a surgir no campo da ficção científica (FC) em obras como "The man who hated flies", de J. D. Beresford (1929), espécie de ecocatástrofe avant la lettre. Stableford (2007) analisa as trocas entre a consciência ecológica e a literatura de FC, abordando questões como o resgate das teorias malthusianas, a "hipótese de Gaia", de James Lovelock, o "Population Council" dos anos 50, a "bomba populacional" de Paul Ehrlich e, finalmente, o Greenpeace, no contexto de abordagens, interpretações ou extrapolações literárias - como a ideia de “terraformação" (terraforming), os impactos ambientais negativos da colonização espacial, leituras antitecnológicas ou até místicas da civilização moderna, engenharia genética e póshumanismo. De livros a filmes, podemos observar um aumento gradual tanto em termos de quantidade quanto de qualidade e relevância dos filmes de "eco-ficção científica" desde os anos 50, mas principalmente nas décadas de 60 e 70 do século 20, em paralelo à escalada de uma consciência ecológica mais identificada com a esquerda em todo o mundo.

As análises de Stableford concernem à tradição literária anglófona ou anglo-saxônica. No entanto, o tempo provou que a ecologia não está limitada a nenhuma nação em particular, sendo a questão ambiental uma preocupação global. E o que dizer da "ficção ambiental"? Sabe-se que o Brasil, entre outros países latino-americanos ou não-ocidentais, inspira em 
observadores estrangeiros o ideal de uma terra exótica, selvagem, muitas vezes até romântica. Isso pode ser visto em filmes como $O$ mundo perdido (The lost world, 1925), de Harry Hoyt (1925), ou O monstro da Lagoa Negra (Creature from the Black Lagoon, 1954), de Jack Arnold, entre vários outros exemplos, dos mais diversos valores orçamentários ou estéticos. Apesar de frequentemente exagerada, essa natureza mitológica é parcialmente nutrida pela própria autoimagem de muitos brasileiros.

Alguns dos filmes aqui discutidos foram produzidos e lançados durante a ditadura militar brasileira (1964-1985), que teve início com o golpe de 1964. Após 1968, com a promulgação do Ato Institucional no 5, o regime endureceu sua repressão contra os cidadãos brasileiros, principalmente os descontentes. 0 chamado "golpe dentro do golpe" colocou os militares mais radicais no poder. Filmes como Manhã cinzenta (1969), de Olney São Paulo, Túnel 93 (1972), de Claudinê Perina Camargo (C. Perina C.), e Parada 88: o limite de alerta (1978), de José de Anchieta, pertencem a esse cenário, enquanto Abrigo nuclear (1981), de Roberto Pires, e Sangue de tatu (1986), de Marcos Bertoni, surgem em período de abertura ou retorno à democracia.

Foi perto do fim dos anos 1970 (precisamente em 1979) que os militares começaram a relaxar parte do controle exercido sobre a sociedade brasileira, e em 1985, graças em parte a uma enorme pressão popular e de opinião pública, o retorno à democracia foi finalmente pactuado com as forças armadas - numa transição obscura e até hoje mal resolvida. As primeiras eleições presidenciais livres ocorreram apenas em 1989. De 89 a 2019, o ambientalismo mundial evoluiu muito, principalmente no Brasil. A instalação do The Intergovernmental Panel on Climate Change (IPCC) da ONU configura-se como um dos principais marcos dessa agenda ecológica mundial. Criado em 1988 pela World Meteorological Organization (WMO) e pelo United Nations Environment Programme (UNEP), o IPCC tem por objetivo prover informações científicas para que os governos ao redor do mundo possam implementar políticas ambientais. Os relatórios do IPCC também têm sido cruciais para as negociações internacionais a propósito das mudanças climáticas.

Outrossim, em cerca de apenas dois anos, desde a posse de Jair Bolsonaro, conseguimos regredir a níveis inimagináveis de degradação ambiental e políticas equivocadas no Brasil. Num espaço de aproximadamente 50 anos, o país passou de vilão a herói do ambientalismo, sendo hoje novamente vilão aos olhos da opinião pública internacional. 0 
governo Bolsonaro conseguiu destruir, em poucos anos, grande parte da imagem do Brasil no debate ambientalista, imagem construída sobretudo a partir dos anos 1990, com a redemocratização e a realização da EC0-92, a Conferência das Nações Unidas sobre o Meio Ambiente e o Desenvolvimento, no Rio de Janeiro. Ou seja, a causa ambientalista continua atualíssima e crucial, uma vez mais, com paralelos e reflexos no cinema brasileiro, seja na ampla e consistente filmografia nacional documentária sobre o meio ambiente, seja em filmes de ficção que abordam ainda hoje, direta ou indiretamente, a questão ecológica. Em outras palavras, as ecodistopias foram instrumentais na crítica ao regime não apenas durante a ditadura militar. Sua instrumentalidade permanece ainda hoje, não apenas em função do retrocesso político, mas também da resiliência da agenda neoliberal.

Nesse sentido, e buscando inspiração no semiopragmatismo de Roger Odin (2005; 2012), sobretudo em seu exemplo de "leitura documentarizante" (2012), procuraremos oferecer uma "leitura ecologizante" de determinados filmes brasileiros - alguns mais, outros menos explicitamente aderentes ao discurso ambientalista ou ao gênero mais evidente das ecodistopias. Dessa forma, filmes que problematizam a cidade ou a desigualdade econômica e social também podem ser lidos numa chave "ecologizante", na medida em que, em muitos casos, suas fábulas e personagens tensionam, de algum modo e em algum grau, a relação do ser humano com seu planeta e demais espécies. Começaremos por um período extremamente sofrido e vergonhoso da história brasileira, quando os filmes ecodistópicos foram praticamente sinônimos de resistência ao regime ditatorial.

\section{A ecodistopia cinematográfica nos anos de chumbo}

No Brasil do regime militar (1964-1985), soma-se à bandeira ambientalista e à ansiedade nuclear em função da Guerra Fria o problema interno da ditadura, em filmes que aludem ficcionalmente a atmosferas virtualmente irrespiráveis. São exemplos dessa filmografia os curtas-metragens Manhã cinzenta, de Olney São Paulo, O fim (1972), de Elie Politi, e Túnel 93º de C. Perina C.

Realizado por Perina e colegas da Faculdade de Comunicação Social da PUC de Campinas, o curta em Super-8 Túnel 93º alterna imagens do futuro apocalíptico, claustrofóbico e subterrâneo com as ternas lembranças da vida na superfície e do convívio com a natureza. 
Diversas imagens de arquivo, nacionais e estrangeiras, retratam o século XX e o avanço da poluição no planeta. Após uma grande catástrofe ambiental, a atmosfera terrestre tornou-se letal para os seres humanos, então obrigados a se refugiar num "abrigo antiatômico e antipoluição". Nessa cidadela subterrânea, as pessoas "recuperam" clorofila e "recobram" oxigênio, no sentido de remediar os malefícios de uma existência privada da atmosfera natural. Cientistas criam seres sem o septo nasal - "esse apêndice inútil" -, e a humanidade se torna mutante. O protagonista, $\mathrm{n}^{\mathrm{0}}$ 34590, tem seu prazo de vida expirado. Ele deve deixar o abrigo rumo à superfície, onde vai sucumbir à alta temperatura e atmosfera venenosa.

Ainda nos "anos de chumbo", é lançado aquele que talvez seja o primeiro e mais potente panfleto ambientalista do cinema brasileiro em longa-metragem (35mm): Parada 88: o limite de alerta, de José de Anchieta. A ação de Parada 88 se passa em dezembro de 1999, 6 anos após uma fábrica explodir espalhando no ar toneladas de dioxina, substância tóxica e corrosiva. 0 vazamento persiste e a população é obrigada a viver trafegando por túneis plásticos que interligam os prédios da cidade, além de pagar pelo ar respirável. Com fotografia de Chico Botelho, o filme de José de Anchieta é praticamente todo imerso na escuridão, no hermetismo dos túneis e construções. Profundamente pessimista, Parada 88 parece antever algo do cyberpunk - ou, se se preferir, tupinipunk ${ }^{1}$ - que se desenvolveria pouco depois, nos anos 1980.

Parada 88 foi realizado com recursos da extinta Embrafilme, na época presidida por Roberto Farias, que teria visto no argumento do filme "uma linguagem nova, diferenciada daquela que era vigente no cinema brasileiro de então, a 'estética da fome'"2. Embora busque o distanciamento da estética cinemanovista, Parada 88 traz alguns aspectos sintomáticos das condições de sua produção, os quais não deixam de constituir uma certa "estética da fome"3

\footnotetext{
1Tupinipunk é o termo cunhado pelo escritor e pesquisador Roberto de Sousa Causo (1996) para designar o cyberpunk brasileiro, manifesto em livros como Santa Clara Poltergeist, de Fausto Fawcett, Silicone XXI, de Alfredo Sirkis, ou Piritas siderais, de Guilherme Kujawski.

2 Entrevista com José de Anchieta, por e-mail, em 30/05/2007.

3 Uso metafórico, aqui, do termo cunhado por Glauber Rocha em sua tese apresentada durante as discussões em torno do Cinema Novo, por ocasião da retrospectiva realizada na Resenha do Cinema Latino-Americano em Gênova, na Itália, em janeiro de 1965. 0 texto foi publicado pela primeira vez na Revista Civilização Brasileira (número 3, julho de 1965), numa versão revisada e acrescida. Posteriormente, o manifesto foi republicado em livros como A Revolução do Cinema Novo (2004). "Eztetyka da Fome 65" pode ser encontrado também, na íntegra, em uma variedade de sites na internet, como o da revista Contracampo (http://www.contracampo.com.br/21/esteticadafome.htm). A tese apresentada por Glauber tensionava a relação entre o cinema brasileiro à época e sua repercussão no Ocidente, propondo uma forma revolucionária para os
}

Dossiê 0 Pensamento Ecológico - https://revistaecopos.eco.ufrj.br/

ISSN 2175-8689 - v. 23, n. 2, 2020

DOI: 10.29146/eco-pos.v23i2.27528 
em comparação ao cinema de FC modelar estadunidense. Isso pode ser verificado no cenário e na fotografia, muito bem solucionados a despeito das restrições orçamentárias. 0 roteiro de Parada 88 foi escrito pelo próprio Anchieta, em colaboração com Roberto Santos, e o filme foi rodado em Paranapiacaba, cidadezinha serrana paulista conhecida por sua clássica neblina. Egresso do teatro, José de Anchieta comenta que deu especial atenção à cenografia e iluminação de Parada 88 no intuito de reproduzir um clima teatral, e que buscou a linguagem do teatro como fio condutor do filme. $\mathrm{O}$ arquiteto Alcino Izzo projetou os complexos túneis de plástico que dominam a cenografia, trazendo para o filme uma contribuição fundamental. ${ }^{4}$ Anchieta declara também que Parada 88 foi feito desde o início com o objetivo de ser um alerta ecológico. A inspiração para o filme veio de seu primeiro filho, que na infância teve sérios problemas respiratórios devidos à poluição de São Paulo. Segundo o diretor, o longa é a somatória de três curtas-metragens anteriores: A Flauta das Vértebras (sem data), Reticências $(1972)^{5}$ e Ponto Final $(1975)^{6}$, os quais funcionaram como ensaios preparativos. ${ }^{7}$ Parada 88 parece refletir em celulóide os primeiros movimentos mais organizados de tomada de consciência ambiental no Brasil. Molina-Gavilán et al. observam que

cinemas nacionais latino-americanos: "Nem o latino comunica sua verdadeira miséria ao homem civilizado nem o homem civilizado compreende verdadeiramente a miséria do latino. (...) A fome latina, por isto, não é somente um sintoma alarmante: é o nervo de sua própria sociedade. Aí reside a trágica originalidade do Cinema Novo diante do cinema mundial: nossa originalidade é nossa fome e nossa maior miséria é que esta fome, sendo sentida, não é compreendida" (Rocha, 1965).

${ }^{4}$ Entrevista com José de Anchieta, por e-mail, em 30/05/2007.

5 Curta-metragem colorido, em $35 \mathrm{~mm}$, com aproximadamente 10 minutos de duração, esta obra ganhou os prêmios de Melhor Filme Brasileiro na Mostra do Filme Científico, 5, 1974, e o Troféu Humberto Mauro no Festival Brasileiro de Curta-Metragem, em 1972, realizado no Rio de Janeiro. Segundo sinopse disponível na Filmografia Brasileira da Cinemateca Brasileira (http://bases.cinemateca.gov.br/cgi-bin/wxis.exe/iah/): "A poluição ambiental não era a única causa da dificuldade de respirar. A censura e a repressão do regime militar eram uma mordaça sufocante que roubava também nosso ar. 0 filme retrata metaforicamente a impossibilidade de expressão" (RIO-CINE/2).

${ }^{6}$ Filme em $35 \mathrm{~mm}$, colorido, com aproximadamente 10 minutos, vencedor de Melhor Curta-metragem com o Troféu Humberto Mauro e Melhor Direção para José Anchieta Costa, no Festival de Gramado de 1975. Segundo sinopse originalmente publicada pela revista Filme Cultura (s.d.), reproduzida na Filmografia Brasileira da Cinemateca Brasileira (http://bases.cinemateca.gov.br/cgi-bin/wxis.exe/iah/): "A história transcorre em tempo e lugar não determinados, onde as pessoas, não podendo mais respirar sem o auxílio de uma máscara, perambulam perdidas pelas ruas poluídas por espessa fumaça. 0 único lugar seguro é um centro de respiração artificial onde as pessoas, em fila, recebem porções limitadas de ar puro através de um grande pulmão inflado. Um homem não participa dos tumultos causados pela ânsia de obter ar e recorta estrelas de papel prateado. No final, num gesto suicida de revolta contra esse tipo de vida, ele sai para a rua, retira sua máscara e morre, lançando ao ar suas falsas estrelinhas, símbolo de um sonho impossível".

${ }^{7}$ Entrevista com José de Anchieta, por e-mail, em 30/05/2007.

Dossiê 0 Pensamento Ecológico - https://revistaecopos.eco.ufrj.br/

ISSN 2175-8689 - v. 23, n. 2, 2020

DOI: 10.29146/eco-pos.v23i2.27528 
[e]m romances distópicos como Umbra (1977), de Plínio Cabral, e Não Verás País Nenhum (1981), de Ignácio de Loyola Brandão, a degradação ambiental caminha de mãos dadas com a erosão das liberdades individuais na medida em que o Brasil enfrenta as conseqüências ecológicas e políticas do regime militar (2007, p. 382)

Segundo Ginway, no Brasil os primeiros movimentos ecológicos teriam começado por volta de 1971 (2005, p. 125). Pouco antes, em 1968, era realizada em Paris a Conferência da Biosfera, de caráter predominantemente científico. Em 1972, o Clube de Roma ganhava visibilidade com a publicação do documento Os limites do crescimento (Meadows et al., 1972). Elaborado por especialistas do Massachussets Institute of Technology (MIT), o documento do Clube de Roma foi bastante influente com a tese de que a redução da industrialização e do crescimento econômico seria o único meio de se evitar uma catástrofe ambiental global. Essa tese, no entanto, ia contra os interesses dos países em desenvolvimento, dentre eles o Brasil. 0 governo militar dependia profundamente do êxito econômico, inclusive como fator de legitimação. Nesse cenário, “(...) o pensamento brasileiro apregoava ser necessário primeiro desenvolver-se, depois 'pagar a conta' dos danos ambientais, tal como haviam feito os países ricos" (Duarte, 2003, p. 17).

Ainda em 1972, a Conferência Mundial das Nações Unidas para o Meio Ambiente, realizada em Estocolmo, estabeleceu novas diretrizes em termos de pesquisa ambiental. A delegação brasileira teve papel combativo em Estocolmo: contestou as postulações dos países ricos e conquistou a simpatia das demais delegações de países em desenvolvimento, como China e Índia. Duarte resume as teses brasileiras levadas à Conferência de Estocolmo da seguinte maneira:

[A] poluição não é um conceito absoluto (como a soberania), mas relativo, e se a interferência humana sobre o meio ambiente fosse tomada em termos absolutos, seria necessário eliminar a humanidade; os países em desenvolvimento não são poluidores, apenas possuem pequenos cistos de poluição; nos países menos desenvolvidos, a degradação ambiental deriva da pobreza, que origina fenômenos como erosão do solo, favelas e queimadas. Com o crescimento econômico a poluição da pobreza pode ser corrigida, e uma parcela do bolo pode ser destinada à correção da poluição dos países desenvolvidos. (Duarte, 2003, pp. 18-9)

A Conferência de Estocolmo foi um palco de debates acalorados, envolvendo o confronto de opiniões essencialmente entre $\quad$ n norte industrializado e $\quad o$ sul em 
desenvolvimento. Gerou também uma série de expectativas e medidas, dentre elas a criação do Programa das Nações Unidas para o Meio Ambiente (PNUMA). Também como consequência de Estocolmo, em outubro de 1973 o governo brasileiro criava a Secretaria Especial do Meio Ambiente (SEMA).

\section{Uma brisa que sopra: ecodistopia em ritmo de abertura}

Foi num cenário político de gradual reabertura que surgia o longa Abrigo nuclear, de Roberto Pires. Com roteiro de Pires e Orlando Senna, o filme trata da problemática da energia nuclear e seu impacto ambiental. Seu argumento pode muito bem ter sido inspirado em algumas ideias do físico César Lattes, conforme sugere Glauber Rocha (2004, p. 464). Curioso observar que o nome do protagonista de Abrigo, interpretado pelo próprio Pires, é nada menos que Lat.

Abrigo foi rodado depois de quatro anos de pesquisa, com uma equipe "topa-tudo", em estúdio construído na orla marítima de Salvador, onde antes Pires havia filmado Redenção (1959) (Miranda, 1990, p. 261). Em Abrigo nuclear, Lat é o encarregado da manutenção de detritos radioativos na superfície. Em sua última inspeção de rotina, constata sérios problemas na estocagem do lixo atômico e risco de explosão que poderia comprometer o abrigo subterrâneo. Mas seu relatório alarmante é considerado insubordinação por Avo (Conceição Senna), a comandante do abrigo que mantém a população subterrânea em estrita disciplina e ignorante de que, no passado, a humanidade já havia habitado a superfície. Lat junta esforços a um grupo clandestino, liderado pela Dra. Lix (Norma Bengell), contrário ao "Sistema Cibernético Nuclear" e dedicado a um plano secreto que visa desativar os reatores nucleares, reabilitar métodos limpos de geração de energia, reformular o modo de vida da sociedade e reconquistar a superfície.

Realizado ainda durante a ditadura militar e lançado mais ou menos na mesma época de publicação da famosa ecodistopia de Ignácio de Loyola Brandão, Não verás país nenhum (1982), Abrigo nuclear foi contemporâneo da euforia atômica do governo brasileiro, que depositava grandes expectativas nas usinas nucleares de Angra dos Reis. Depois de Abrigo, Roberto Pires escreveu e dirigiu o docudrama Césio 137: pesadelo de Goiânia, filme de 1989/90. Assim como Brasil ano 2000 (1969), de Walter Lima Jr., e Parada 88, Abrigo nuclear 
também se vale da FC como interface para a crítica social e política no contexto da ditadura militar. Todos esses três filmes recorrem à imagem da "terra devastada", ou wasteland, nos termos de Gary K. Wolfe $(1979)^{8}$, como alegoria instrumental na diatribe do regime ditatorial e seu "modernismo reacionário".

Cerca de dois anos após o lançamento de Abrigo nuclear, em 1983, a agenda ambientalista mundial ganhava novo impulso com a convocação, pela ONU, de uma comissão de especialistas presidida pela norueguesa Gro Harlem Brundtland - que em 1987 apresentará o documento "Nosso Futuro Comum", também conhecido como "Relatório Brundtland", no qual é discutido o estado do meio ambiente do planeta e novos rumos recomendáveis para a sua gestão. Esse documento consolida a expressão "desenvolvimento sustentável". Enquanto isso, no Brasil, entre 83 e 84 toma forma o movimento civil das Diretas Já. A possibilidade dessas eleições foi o objetivo da proposta de emenda constitucional Dante de Oliveira, que, no entanto, terminou rejeitada. Mesmo assim, a redemocratização brasileira já havia atingido um ponto de não-retorno, e o movimento Diretas Já conquistava uma vitória parcial quando Tancredo Neves foi eleito presidente pelo Colégio Eleitoral. Com a morte súbita de Tancredo pouco após sua vitória, assumiria a presidência o vice José Sarney, político alinhado à ditadura, porém o primeiro civil a ocupar o cargo em cerca de 21 anos. Chegava ao fim o regime militar. Mas o cinema brasileiro ainda teria muito a dizer sobre o período.

Um filme que circulou nas franjas da redemocratização foi Sangue de tatu (1986), de Marcos Bertoni, curta-metragem que ganhou o prêmio de Melhor Enredo Ficção Super-8 no XVII Festival de Gramado de 1989. Sangue de tatu surge imbuído de um espírito ecológico que ganhou força nos anos 70 e 80, e narra a epopeia de um funcionário (Henrique Zanetta) da usina nuclear de Angra que, após vazamento, foge para as montanhas. 0 governo militar e a submissão ao capital ou interesses estrangeiros sofrem as críticas mais diretas nessa fita de teor notadamente político, conforme se verifica nas cenas envolvendo o diretor da usina, um "gringo" (Louis Chilson) a serviço dos militares. Após o vazamento do reator, o diretor da usina dirige-se a um abrigo nuclear onde estão guardadas uma miniatura da Estátua da Liberdade e esculturas deformadas dos rostos dos generais da ditadura. Essas esculturas,

\footnotetext{
80 termo wasteland pode ser compreendido em português como terra arrasada, destruída, estéril, ou como "terra inútil", opção escolhida por Paulo Mendes Campos (1956) em sua tradução do poema "The Waste Land", de T. S. Eliot. Sem dúvida, a metáfora de wasteland trabalhada por Gary Wolfe remete-nos ao poema de Eliot. Agradeço à revisora ou revisor anônima/o deste artigo pela lembrança desse traçado.
}

Dossiê 0 Pensamento Ecológico - https://revistaecopos.eco.ufrj.br/

ISSN $2175-8689-$ v. 23, n. 2, 2020

DOI: 10.29146/eco-pos.v23i2.27528 
feitas por Bertoni para uma exposição por ocasião da abertura política, em 1985, são as mesmas de outro curta do cineasta, Recuerdos da República (2002), eleito Melhor Filme no 8. o Festival de Cinema Super-8 de Campinas, em 2003. Quando a usina nuclear finalmente explode, o diretor acaba morto, transfixado pela miniatura da Estátua da Liberdade que cai de seu pedestal. Enquanto isso, o ex-funcionário da usina sobrevive ao desastre nuclear sendo finalmente acolhido por um caboclo (Olavo Ribeiro) habitante das montanhas. 0 filme termina inconcluso, mas com um claro aceno à reconciliação do homem com a natureza e o elogio de formas de energia mais limpas.

Túnel 93ํㅜ Parada 88 e Abrigo nuclear refletem os primeiros sinais de uma nova sensibilidade em relação ao meio-ambiente no Brasil. Esses filmes também encampam em certa medida um discurso anti-moderno ou anti-tecnológico. Em Parada 88, por exemplo, o protagonista e sua família abandonam a cidade. Da mesma forma, em Abrigo nuclear Lat troca a cidade subterrânea por uma vida idílica à beira-mar, desprovida de toda a tecnologia que ele antes desfrutava. Além de seu caráter anti-imperialista, Sangue de tatu também tem uma aspiração anti-moderna marcante na figura do senhor caboclo que socorre o funcionário, personagem repositório de uma suposta sabedoria popular, em oposição à ganância e truculência de cientistas e militares. Pivô da oposição entre a comunhão com a natureza (passado) e o envenenamento pela tecnologia (futuro), o caboclo obtém toda a energia que necessita por meio da força da água, e representa um modo de vida "limpo". É esse mesmo personagem, real, que encerra o curta, declarando ser imune a qualquer malefício (inclusive radioatividade) pois, quando nasceu, sua mãe o havia banhado em sangue de tatu.

Nesse sentido, a nostalgia se apresenta como um valor de destaque nas ecodistopias brasileiras. No caso de Parada 88, é esse sentimento, aliado à necessidade, que move o personagem Joaquim Porfírio (Joel Barcellos), bem como boa parte da população isolada. Nostalgia pelo ar puro, pelo passado sem a mácula da modernidade. Essa mesma nostalgia também está presente em Abrigo nuclear, no desejo rebelde de descobrir e reviver o passado, e em Túnel 93o, especialmente no âmbito das imagens referentes às memórias do protagonista, comentadas pelo poema de Hiládio Brito. Sobrevém uma visão romântica, ou até mesmo um certo ludismo em relação ao desenvolvimento econômico sob o regime militar, perceptível através do tratamento nostálgico e da recorrência à natureza nos filmes até então comentados. Ilustram esses sentimentos, de forma ambivalente e por vezes irônica, os falsos 
“índios” em Brasil ano 2000, mas também as locações externas em Abrigo nuclear ou em Quem é Beta? (1972), de Nelson Pereira dos Santos. Brasil ano 2000 e Quem é Beta? também podem ser incluídos no rol das ecodistopias brasileiras, nas quais a modernidade, associada ao militarismo e à burocracia, traz consigo o aprisionamento e a privação da natureza, o que se traduz num atentado à identidade mais genuinamente nacional e popular. Túnel 93ำ também não esconde seu alinhamento a um certo discurso de esquerda ao ilustrar a escalada da degradação do planeta com imagens de desfiles nazistas. 0 filme de C. Perina C. é o único em que o protagonista realmente sucumbe à atmosfera poluída. Tanto em Abrigo nuclear quanto em Parada 88, os personagens acabam se expondo à atmosfera sem graves consequências imediatas, contrariando as determinações do status quo e abrindo possibilidades de mudança. Um ditado infame e pitoresco era bem conhecido na época da ditadura militar: "Brasil: ame-o ou deixe-o". Os protagonistas das ecodistopias brasileiras não se furtam a deixar o país em caso de necessidade ou "força maior", exprimindo um pessimismo latente. O herói da ecodistopia brasileira será, sobretudo, um exilado.

Naturalmente, além de filmes-manifesto contra a modernização desenfreada e despreocupada em relação ao meio-ambiente, os títulos comentados aqui também podem ser lidos como críticas de alcance mais geral em relação à conjuntura econômica, social e política do país no período militar, parábolas que representam uma sociedade sob pressão, incapaz de respirar ar puro e sujeita a ameaças e poderes invisíveis, burocráticos e autoritários. ${ }^{9}$ Em Parada 88, por exemplo, filme dirigido por um ex-integrante do Partido Comunista, o Estado é um grande ausente, um fantasma opressor cujo poder se faz sentir por meio de proibições, protocolos e cobranças. Conforme se verifica em diálogo na cena da reunião no Departamento de Controle de Gases, a quarentena tão prolongada da cidade é resultado da burocracia no governo. Numa leitura superposta ao contexto histórico do filme, a paixão de Ana (Regina Duarte), a filha de Joaquim, por Cara-de-Anjo (Terence Tullgren), o cobrador que a violenta, pode ser encarada como metáfora de uma população cega, impotente e fascinada por seu opressor. Ana deixa a cidade a contragosto, revoltada contra o pai por este ter matado Cara-deAnjo. 0 filme termina com Ana aos gritos de "eu te odeio" contra o pai.

\footnotetext{
${ }^{9}$ Curioso notar que os anos de lançamento de três dos filmes aqui analisados - 1972, 1978 e 1981 - coincidem com o período da literatura brasileira de FC que Roberto de Sousa Causo (1996) denomina "Crítica ao Regime" ou "Dispersão", de 1971 a 1982, e que Ginway aponta como período de emergência da ficção distópica brasileira (Ginway, 2005, pp. 93-140).
}

Dossiê 0 Pensamento Ecológico - https://revistaecopos.eco.ufrj.br/

ISSN $2175-8689$ - v. 23, n. 2, 2020

DOI: 10.29146/eco-pos.v23i2.27528 
José de Anchieta comenta que adotou a metáfora como linguagem em Parada 88 para se proteger da censura, mas esta nunca o teria perturbado de fato. A crítica cinematográfica é que teria sido bastante agressiva em relação a seu filme. ${ }^{10}$ Curiosíssimo notar, em retrospecto, como Parada 88 pode ser visto como alegoria do Brasil em 2020, durante a pandemia de Covid-19. A cidade em quarentena, seus habitantes entregues à própria sorte, humilhando-se e arriscando-se a troco de sobrevivência, o isolamento e a ameaça que paira no ar não parecem imagens distantes. E o fascínio da personagem de Regina Duarte pelo violador parece premonitório daquilo que veríamos mais recentemente quando a atriz, agora na terceira idade e exercendo a função de Secretária de Cultura no governo Bolsonaro, banalizou a morte, a tortura e o fascismo numa entrevista exclusiva ao canal CNN, transmitida pela primeira vez no dia 7 de maio de 202011. Por ocasião dessa entrevista, Regina Duarte minimizou a ditadura afirmando que "sempre houve tortura e que não quer arrastar um cemitério".

\section{Com a água no pescoço: a ecodistopia na Retomada}

A redemocratização reconfigurou a consciência ecológica no Brasil e reabilitou a imagem do país no exterior. Em 1988, na esteira do Relatório Brundtlant, a Assembleia Geral da ONU aprovou resolução determinando a realização de nova conferência internacional para avaliar os avanços desde Estocolmo. O Brasil se oferece como sede da conferência e a proposta é aceita. Duarte observa que, na segunda metade da década de 80, “os refletores internacionais focalizavam o Brasil como o pior vilão ambiental em atividade" (2005, p. 31). Essa fama ante os olhos da opinião pública internacional era fruto da política militar de desenvolvimento pouco ou nada preocupada com a degradação ambiental, acirrada pelo avanço do desmatamento na Amazônia.

Com a retomada do cinema brasileiro a partir de 1993/4, o ambientalismo voltava a disputar espaço em filmes como Oceano Atlantis (1993), de Francisco de Paula, ou Acquaria

\footnotetext{
10 Entrevista com José de Anchieta, por e-mail, em 30/05/2007.

${ }^{11}$ A matéria do canal CNN, sob o título "Exclusivo: Regina Duarte minimiza ditadura e interrompe entrevista à CNN", pode ser visualizada no YouTube em https://www.youtube.com/watch?v=v9gLHrP7RNw. A ex-atriz foi exonerada do cargo de Secretária de Cultura pouco depois do incidente, mas é pouco provável que seu desempenho na entrevista tenha tido relação direta com sua exclusão do governo, uma vez que este é abertamente tolerante, senão defensor da ditadura, da tortura e do cerceamento da liberdade de expressão, conforme diversas atitudes e declarações do presidente ao longo de sua carreira como figura pública.
} 
(2005), de Flávia Moraes. ${ }^{12}$ Rodado entre 1989 e 1993 e jamais lançado comercialmente, Oceano Atlantis apresenta o Rio de Janeiro num futuro indeterminado, depois de um dilúvio que deixou boa parte da cidade submersa, obrigando as pessoas a viverem na encosta dos morros. 0 protagonista é um mergulhador mercenário (Nuno Leal Maia) que foge de um hospício, vai viver na favela e começa a mergulhar regularmente, em busca de alimentos e de algum tesouro perdido, supostamente atendendo a interesses de gente poderosa. Num desses mergulhos ele vai parar numa região submersa onde vivem descendentes da "civilização atlante".

O filme refere-se a uma catástrofe ambiental decorrente do aquecimento global e consequente derretimento dos polos, razões pelas quais o nível dos oceanos se eleva, forçando os sobreviventes a buscar refúgio em regiões mais altas (como as favelas cariocas) e lidar com a escassez de alimentos. Na sociedade utópica subaquática as pessoas gozam de prosperidade. Arduíno Colasanti interpreta o sábio da civilização submarina; Antônio Abujamra, um cientista da mesma comunidade; e Dercy Gonçalves, então com 84 anos, interpreta uma atlante muda que, como os demais integrantes de sua tribo, se comunica por telepatia. Por esse papel, Dercy ganhou o prêmio de Melhor Atriz Coadjuvante no XXVI Festival de Brasília de 1993. Oceano Atlantis une características do filme-catástrofe com a tradição das lendas sobre o continente perdido. Imagens documentárias dos trens, favelas e outras paisagens cariocas são intercaladas à narrativa ficcional, fotografada por Dib Lufti e Pedro Farkas, com algumas cenas rodadas em Fernando de Noronha.

Filmes como Oceano Atlantis e Acquaria, embora pós-apocalípticos, parecem esvaziados de uma dimensão política mais acirrada e embalados num certo otimismo coincidente com uma virada de jogo nas negociações internacionais sobre o meio ambiente. Na Eco-92 (continuação da Conferência Mundial das Nações Unidas para o Meio Ambiente), realizada no Rio de Janeiro em 1992, ganha vulto em meio à opinião pública a noção de que os países altamente industrializados são os verdadeiros responsáveis pela poluição do planeta. A partir da Eco-92 surgem documentos e medidas como a Agenda 21 e, mais tarde, o Protocolo de Kyoto (1997). A conferência do Rio ajudou o Brasil a reverter sua imagem de "grande vilão

\footnotetext{
12 Não discutiremos Acquaria por uma questão de prioridade, dada a restrição do espaço reservado a esta discussão. A nosso ver, o filme pouco acrescenta em termos de abordagem inovadora da FC cinematográfica ecodistópica brasileira.
}

Dossiê 0 Pensamento Ecológico - https://revistaecopos.eco.ufrj.br/

ISSN 2175-8689 - v. 23, n. 2, 2020

DOI: 10.29146/eco-pos.v23i2.27528 
ambiental", suscitando intensos debates que extrapolaram as esferas oficiais. A essa altura, o movimento ambientalista já estava consolidado ao redor do mundo, inclusive em alguns países pobres. Enquanto isso, os EUA começavam a encarar as novas propostas ambientalistas como entraves à manutenção de sua economia, a maior e mais poluente do planeta. "Ironicamente, os cartazes de protesto identificavam não mais o Brasil como o vilão ambiental, mas os Estados Unidos" (Duarte, 2005, p. 43).

$\mathrm{Na}$ conferência seguinte, realizada em Joanesburgo, 2002, o Brasil mudou sensivelmente o seu discurso em relação a Estocolmo, admitindo que "a pobreza não deveria servir de pretexto para afastar a percepção do agravamento dos problemas ambientais" (Duarte, 2005, p. 54). Embora Joanesburgo tenha representado poucas conquistas, a diplomacia brasileira contabilizou "como êxito a manutenção de princípios firmados na Rio92, como a responsabilidade comum mas diferenciada para os países desenvolvidos e em desenvolvimento" (Duarte, 2005, p. 56). Mesmo com a desaceleração do desmatamento da Amazônia naquele período, o Brasil continuava enfrentando velhos problemas ambientais, somados a novos, como a biopirataria, a questão dos transgênicos e outros. De toda maneira, no decorrer das décadas de 90 e 2000, uma maior preocupação ambiental por parte do Estado brasileiro - manifesta por meio da atuação de instituições como o Ministério do Meio Ambiente e o Instituto Brasileiro do Meio Ambiente e dos Recursos Naturais Renováveis (o IBAMA, uma autarquia federal criada pela Lei no 7.735 de 22 de fevereiro de 1989), do estabelecimento de programas de preservação ambiental e do desenvolvimento de tecnologias para matriz energética renovável (álcool, biodiesel) - acabou por afastar o Brasil da imagem de grande predador do planeta. Um possível divórcio momentâneo entre ativismo político e ambientalismo no cinema de ficção brasileiro pareceu refletir um pouco de otimismo, na medida em que a questão do meio ambiente parecia reconhecida e ocupava cada vez mais espaço na agenda internacional.

\section{0 circo pega fogo: a ecodistopia nos últimos 10 anos.}

Mais recentemente, diante da escalada do negacionismo científico, das controvérsias envolvendo o agronegócio, da ascensão de governos de extrema direita e do recrudescimento da devastação na Amazônia, a ecodistopia parece revisitar o cinema brasileiro, novamente 
imbricada com uma crítica social e política mais intensa. Assim, a um só tempo a história do Brasil, as estruturas de poder no país, o neoliberalismo e o colapso do meio ambiente têm sido discutidos, sob forma de alegorias ou parábolas, em filmes de curta e longa-metragem relativamente recentes, bem como em séries para web ou streaming.

Rodado em 35mm em Recife-PE, o mockumentary (documentário falso) Recife frio (2009), de Kléber Mendonça Filho, emula um programa de televisão argentino que está cobrindo um curioso fenômeno climático na capital pernambucana. Sem razão aparente, Recife deixa de ser uma cidade tropical e passa a registrar temperaturas dignas do inverno europeu. O "programa de TV" embutido no filme tem por propósito expor o impacto dessa "catástrofe climática" sobre a população recifense. Partindo de uma situação totalmente absurda, Recife frio entabula uma crítica à formação social, econômica e política do Brasil. 0 filme adere a uma forte tradição satírica da literatura e do cinema de FC, operando um argumento lógico do tipo reductio ad absurdum. Revisto em 2020, no entanto, o absurdismo do filme parece perder algo de sua força, na medida em que o então ministro interino da saúde do governo Bolsonaro, general Eduardo Pazuello ${ }^{13}$, afirmou, em pronunciamento oficial, que as regiões norte e nordeste do Brasil têm clima dependente (sic) do hemisfério norte do planeta. $^{14}$

Uma das cenas mais inspiradas e críticas em Recife Frio é aquela que enfoca os Nogueiras, "vítimas arquitetônicas do frio". Família de classe média-alta que vive em apartamento de luxo à beira-mar, os Nogueiras estão agora em perigo devido à inadequação de sua propriedade ao novo clima da região. As amplas janelas e varandas que fazem os ambientes bem ventilados, projetados para uma cidade tropical, agora tornam sua casa inóspita. 0 jovem filho mimado, no entanto, consegue escapar do frio indo para o quarto de empregada. A narração em voz over comenta a luta de classes que ocorre no seio dessa família.

\footnotetext{
13 Tornado general do exército pouco antes de tomar posse como ministro interino da pasta de Saúde em 15 de maio de 2020, após pedido de exoneração do médico Nelson Teich, Eduardo Pazuello permaneceu por quatro meses no cargo, em plena ascensão da pandemia de Covid-19 no Brasil, até ser tornado ministro da Saúde definitivo, devidamente empossado em 16 de setembro de 2020. Segundo dados oficiais do próprio Ministério da Saúde (https://covid.saude.gov.br/), o Brasil apresentou, até o dia 23 de setembro de 2020, 4.591 .604 casos confirmados de Covid-19, com 138.108 mortos vítimas da doença.

${ }^{14}$ As declarações - no mínimo equivocadas - do ministro foram gravadas em vídeo e repercutidas por diversos órgãos de imprensa (e.g. O Dia, Catraca Livre, Revista Fórum). Segundo matéria do jornal O Dia: "O ministro interino da Saúde, general Eduardo Pazuello, afirmou, nesta terça-feira [9 de junho de 2020], que algumas regiões do Brasil já estariam na reta final do coronavírus por conta de seu clima. Ao justificar a informação, ele disse que 'a região Norte e Nordeste (do Brasil) está mais ligada ao inverno do hemisfério Norte"'.
}

Dossiê 0 Pensamento Ecológico - https://revistaecopos.eco.ufrj.br/

ISSN $2175-8689-$ v. 23 , n. 2, 2020

DOI: 10.29146/eco-pos.v23i2.27528 
Como explicado, o quarto da empregada é uma "instituição brasileira", reminiscência da escravidão ou fantasma dos tempos da senzala. Sempre a área menor e mais abafada de qualquer casa ou apartamento brasileiro, o quarto da empregada dificilmente tem janelas e costuma estar localizado na parte de trás dos edifícios. 0 filho explica que o quarto da empregada é agora o lugar mais quente e aconchegante do apartamento, por isso ele decidiu se mudar para lá, deixando sua ampla suíte para Gleice, a empregada. Os pais explicam que Gleice não está feliz com isso, pois agora ela enfrenta $4^{0} \mathrm{C}$ no quarto do filho. A Sra. Nogueira acrescenta que Gleice está se sentindo "um peixe fora d'água", pois ela nunca foi acostumada a dormir numa suíte. Mas a vontade do filho do patrão prevalece e Gleice acata as ordens resignada, como tradicionalmente esperado em assuntos de classe e trabalho no Brasil. Essa cena, uma das mais eloquentes do filme, fornece uma boa parábola do legado da escravidão e da persistência de estruturas arcaicas no Brasil contemporâneo. Além disso, a cena comenta a deletéria especulação imobiliária nas cidades brasileiras e a falta de um planejamento urbano adequado. Nesse sentido, Recife frio se destaca como legítima ecodistopia brasileira no contexto cinematográfico mais recente, podendo somar-se ainda a outros filmes mais focados no tema do urbanismo ou especulação, como Banco Imobiliário (2016), de Miguel Antunes Ramos, ou Um lugar ao sol (2015), de Gabriel Mascaro.

Nesse contexto mais contemporâneo, aparentemente livre de censura, o cinema de FC continua codificando, esporadicamente, narrativas que tensionam a memória da ditadura militar, reativando a problemática ambiental atrelada à história de autoritarismo e exclusão no Brasil. Esse é o caso do longa de animação Uma história de amor e fúria (2013), de Luiz Bolognesi, filme que revisita a história do Brasil ao longo de aproximadamente 600 anos, sob o ponto de vista de um índio tupinambá (Selton Mello), personagem imortal que atravessa os séculos à procura das reencarnações de sua amada (Camila Pitanga), enquanto luta em defesa do povo oprimido. Vale a pena observar aqui o retorno das temáticas ecodistópica e espiritualista - ainda que inspirada em lendas indígenas. ${ }^{15} 0$ protagonista enfrenta primeiramente a batalha contra os portugueses e os tupiniquins, depois lidera a Balaiada, no Maranhão, participa do movimento de resistência contra a ditadura militar, na década de 60, até finalmente se deparar com a guerra pela água, no Rio de Janeiro de 2096. Em todos esses

15 A novela infanto-juvenil de Erico Verissimo As aventuras de Tibiquera (1937) é uma fantasia que também apresenta um índio imortal que testemunha os desenvolvimentos da história do Brasil.

Dossiê o Pensamento Ecológico - https://revistaecopos.eco.ufrj.br/

ISSN $2175-8689$ - v. 23 , n. 2, 2020

DOI: 10.29146/eco-pos.v23i2.27528 
momentos, o filme problematiza a vocação histórica do Brasil para o autoritarismo, seja em contexto monárquico/colonial (Balaiada), militar (anos 60), ou de parceria pública e privada (futuro especulativo). 0 caráter ecodistópico do filme de Bolognesi evidencia-se já em seu título internacional, Rio 2096, e nos cartazes de divulgação, bem como na fábula sobre um futuro de escassez e exclusão crescentes. A ideia de controle corporativo da água nos remete a Sleep dealer (2008), longa de Alex Rivera, enquanto a descrição de um Rio cyberpunk pósapocalíptico relembra a atmosfera da Bogotá futurista de En agosto (2009), curta colombiano de Andrés Barrientos e Carlos Andrés Reyes, sobre dois personagens vivendo em duas realidades temporais diferentes, fábula que também mescla lenda indígena e distopia futurista. Em sua revisão da história oficial do Brasil e de seus heróis nacionais, Uma história de amor e fúria aborda questões identitárias sob uma perspectiva pós-colonial - em outras palavras, o filme problematiza a nação como narrativa, parafraseando a tese de Homi Bhabha (1990) sobre a construção ambivalente dos discursos nacionais em desacordo com o passado. Como explica Bhabha,

A crítica pós-colonial é testemunha das forças desiguais e irregulares de representação cultural envolvidas na competição pela autoridade política e social dentro da ordem do mundo moderno. As perspectivas pós-coloniais emergem do testemunho colonial dos países do Terceiro Mundo e dos discursos das "minorias" dentro das divisões geopolíticas de Leste e Oeste, Norte e Sul. Elas intervêm naqueles discursos ideológicos da modernidade que tentam dar uma "normalidade" hegemônica ao desenvolvimento irregular e às histórias diferenciadas de nações, raças, comunidades, povos. Elas formulam suas revisões críticas em torno de questões de diferença cultural, autoridade social e discriminação política a fim de revelar os momentos antagônicos e ambivalentes no interior das "racionalizações" da modernidade. (1998, p. 240)

Vencedor do prêmio de Melhor Filme no Festival de Annecy de 2013, na França, Uma história de amor e fúria parece oferecer um discurso contra-hegemônico que contribui, a seu modo ${ }^{16}$, para o bojo de uma perspectiva pós-colonial no cinema brasileiro mais recente.

\footnotetext{
${ }^{16}$ Conforme explicado por Bhabha, "A perspectiva pós-colonial - como vem sendo desenvolvida por historiadores culturais e teóricos da literatura - abandona as tradições da sociologia do subdesenvolvimento ou teoria da 'dependência'. Como modo de análise, ela tenta revisar aquelas pedagogias nacionalistas ou 'nativistas' que estabelecem a relação do Terceiro Mundo com o Primeiro Mundo em uma estrutura binária de oposição. A perspectiva pós-colonial resiste à busca de formas holísticas de explicação social. Ela força um reconhecimento das fronteiras culturais e políticas mais complexas que existem no vértice dessas esferas políticas frequentemente opostas" (1998, p. 241-242). Uma história de amor e fúria parece contribuir com essa perspectiva em alguma medida, muito embora o filme não venha a tensionar mais profundamente aspectos
}

Dossiê 0 Pensamento Ecológico - https://revistaecopos.eco.ufrj.br/

ISSN $2175-8689-$ v. 23 , n. 2, 2020

DOI: 10.29146/eco-pos.v23i2.27528 
Finalmente, o encontro mais intenso e recente entre a ecodistopia e o comentário político talvez possa ser buscado na série 3\%, criada por Pedro Aguillera e produzida pela Netflix (2016-2019). Ao longo de três temporadas, a série narrou a trajetória de personagens que transitam entre dois mundos: um utópico, a ilha do Maralto, e outro distópico, desértico, insalubre e colapsado, o Continente (identificado com o Brasil). A série gira em torno de um processo seletivo que, a cada ano, seleciona $3 \%$ dos jovens candidatos à imigração para o Maralto, uma ilha de prosperidade e equilíbrio ecológico que mantém, pelo uso da força, uma massa de excluídos no continente depauperado. Não apenas o mar, mas também o famigerado processo e uma força policial fascista garantem o acesso de alguns poucos às maravilhas tecnológicas, abundância e harmonia do Maralto. Ao longo dos episódios que compõem as três temporadas, os personagens tomam atitudes que ora robustecem, ora fragilizam esse sistema excludente de concentração de prosperidade. E assim, uma vez mais, a temática ambiental se justapõe ou se confunde com uma revisão da história do Brasil, de seu passado e presente de desigualdade, violência e exclusão, com poucas perspectivas entusiasmadas de futuro. Como, por exemplo, o episódio 4 da segunda temporada, dirigido por Jotagá Crema, em que o personagem Marco (Rafael Lozano) pensa na história de sua família, os Álvares, pois cada ascendente dele conseguiu seu passaporte para o Maralto. Esse episódio, talvez um dos melhores de toda a série, parece uma releitura condensada do pensamento de Sérgio Buarque de Holanda, entre outros autores, com críticas à manutenção de uma falsa meritocracia no Brasil, tudo sob o pano de fundo da ecodistopia. A terceira temporada de $3 \%$, talvez a mais fraca, irregular e desalentadora de todas, coincide com a presidência de Jair Bolsonaro.

Mais recentemente, a quarta e última temporada de 3\%, lançada em agosto de 2020, resgata algo da fluidez narrativa e da espessura dramática de alguns de seus personagens. A fim de resolver e amarrar as linhas narrativas até então, a quarta temporada parece lançar mão de algumas simplificações, recorrendo mesmo ao deus ex machina em alguma medida. Em todo caso, a conclusão da saga oferece um discurso pacifista, atinente à tolerância e à necessidade não apenas de ação, mas também de congregação - a música de Chico César

relativos à forma narrativa (a opção é pela transparência), e tenda a simplificar nuances da história e das relações de força entre classes, nações e atores políticos - a própria opção por uma "jornada do herói" propelida por uma história de amor traz implicações nesse sentido. De todo modo, talvez até mesmo por se tratar de um filme de animação voltado também a faixas de público mais jovem (e.g. adolescentes e jovens ao redor dos 18 anos de idade), acabam sendo compreensíveis a maioria das concessões eventualmente presentes no filme.

Dossiê o Pensamento Ecológico - https://revistaecopos.eco.ufrj.br/

ISSN $2175-8689$ - v. 23 , n. 2, 2020

DOI: 10.29146/eco-pos.v23i2.27528 
sublinha tais ideias, ditando o ritmo do movimento reorganizador da sociedade. Essa mensagem claramente confronta o estado das coisas no Brasil atual, a polarização política e a intolerância. A dimensão ecológica soma-se ao substrato político: na conclusão de 3\%, prevalece a tese de que não é possível sobreviver, nem construir um futuro, a partir de cesuras autoritárias. 0 problema ambiental não pode ser compartimentado, não permanece infinitamente restrito a um determinado espaço geográfico ou estrato social. A questão ecológica é um desafio global, acirrado por conflitos de raça, classe ou nações, e algum dia todos esses conflitos terão de ser superados. Em seu conjunto, as quatro temporadas de 3\% parecem sugerir que o problema ambiental nunca será definitivamente resolvido apenas e exclusivamente por meio da ciência e da tecnologia cibernética ou computacional, a maior parte do tempo abundantes e super-avançadas no seu Maralto fictício. Um equilíbrio assim, amparado apenas em tecnologia e na otimização de recursos, resulta frágil - um simples pulso eletromagnético põe fim ao Éden e promove o retorno dos anjos decaídos. É preciso ascender a um novo patamar de avanço social, a resolução precisa ser buscada numa ciência e tecnologia sociais mais avançadas, humanistas e inclusivas - algo tentado no âmbito da terceira temporada, em torno da comunidade alternativa ao Maralto, a Concha, situada no continente e dependente de tecnologias mais sustentáveis. O futuro está na humanidade, mais do que para muito mais além dela mesma. Num certo nível, o discurso ambientalista de 3\% acena com ideais afrofuturistas ${ }^{17}$ adaptados ao contexto brasileiro, bem como parece incorporar uma estética da reciclagem originalmente associada ao cyberpunk, mas também presente no tupinipunk brasileiro e em narrativas pós-apocalípticas que buscam nas ruínas, no lixo e nos dejetos uma iconografia premonitória do futuro. 0 caráter inclusivo do elenco de $3 \%$, ampliado a ponto de incluir personagens portadores de necessidades especiais, uma personagem trans e uma protagonista mulher e afrodescendente, parece enfatizar a mensagem ecológica subjacente à trama política central à série.

Todos esses filmes, somados ainda a alguns outros títulos, como Branco sai, preto fica (2014) e Era uma vez Brasília (2017), de Adirley Queirós, ou Brasil S/A (2014), de Marcelo

\footnotetext{
${ }^{17}$ Afrofuturismo é um termo geralmente atribuído a Mark Dery e surgido no começo dos anos 1990, sobretudo a propósito da entrevista de Dery (1994) com artistas/intelectuais como Samuel R. Delany, Greg Tate e Tricia Rose. Segundo o glossário de termos da Tate Modern britânica, "Afrofuturismo é uma estética cultural que combina ficção científica, história e fantasia para explorar a experiência afro-americana, e visa conectar aqueles da diáspora negra com sua ancestralidade africana esquecida" (https://www.tate.org.uk/art/artterms/a/afrofuturism).
} 
Pedroso, adentram - alguns mais, outros menos explicitamente - uma perspectiva ecodistópica. A ecodistopia está presente em Branco sai, preto fica, por exemplo, não apenas no urbanismo fraturado da cidade em clima de apartheid, mas também na própria geografia acidentada e mutilada dos corpos de seus personagens. Enquanto atores que representam a si mesmos, Marquim e Shockito trazem em seus corpos as marcas da exclusão e do autoritarismo (um índice indelével da realidade fabulada), da falência de um projeto urbano moderno tentado em pleno planalto central. 0 filme apresenta uma cidade-monumento de circulação restrita, a maior parte do tempo fora-de-campo, mas que, imaginada em seu conjunto e em retrospecto, ganha os contornos funestos de um enorme mausoléu. A seu modo, mas também um pouco da mesma forma, é a máquina do capital - locomotiva da exploração irrefreada de recursos naturais e da concentração de riquezas - que promove a desigualdade econômica e a cesura social que, em Brasil $S / A$, sugerem a falência do futuro. Não à toa, nesse filme, o personagem principal é um cortador de cana que vem se tornar astronauta. A máquina transforma o país e as pessoas. 0 filme abre com imagens em plongée da água do mar singrada pela proa de um navio. São cenas de uma embarcação entregando tratores destinados a uma plantação de cana-de-açúcar, esse produto tão central na história econômica (e da escravidão) do Brasil. A água e a terra são os elementos predominantes nesse começo da narrativa. Cada vez mais máquinas aparecem no filme, assumem o lugar de personagens e transformam agudamente a paisagem. As cenas finais alternam plongée e contra-plongée, buscando no céu uma ambivalente perspectiva de futuro. Mas a luz é ofuscante, atravessa o centro da bandeira nacional, e a visão termina prejudicada por um estranho eclipse, talvez premonitório.

É um pouco nesse sentido que tais filmes retomam um discurso de crítica à exclusão e à violência histórica no Brasil com amplo impacto no meio ambiente e nas vivências urbanas em diferentes regiões do país. Isso parece mais evidente porque, para surpresa do mundo, o atual governo brasileiro vira ostensivamente as costas para o meio ambiente, nossa biodiversidade, nossas reservas naturais e nações indígenas. Por outro lado, afaga grileiros e garimpeiros, faz vista grossa aos crimes contra nosso patrimônio ambiental e esvazia o poder fiscalizador do IBAMA. Vivemos uma ecodistopia fora das telas.

Recentemente, o ministro da economia do governo Bolsonaro, Paulo Guedes, repetiu de maneira simplória e enviesada a antiga tese da década de 1970, segundo a qual a degradação ambiental resultaria da pobreza. Guedes declarou, durante uma apresentação oficial no Fórum 
Econômico Mundial em Davos, Suíça, em 21 de janeiro de 2020, que "as pessoas destroem (sic) o meio ambiente porque precisam comer". Como se o desmatamento desenfreado não fosse responsabilidade da indústria do agronegócio ou de agricultores gananciosos que multiplicam seus lucros ao arrepio da lei, ou como se a poluição massiva do ar e da água não devesse ser atribuída às grandes indústrias e empresas de mineração. Para mencionar apenas um exemplo breve e recente, a gigante mineradora Vale do Rio Doce foi responsabilizada pelos desastres ecológicos consecutivos de Mariana e Brumadinho, no estado de Minas Gerais, resultando em centenas de mortes de cidadãos brasileiros, mortes incontáveis de animais e plantas e danos sem precedentes aos ecossistemas regionais. Assim, a política ambiental do governo Bolsonaro parece ser, na verdade, anterior ao debate em Estocolmo, 1972.

Segundo o cientista Paulo Artaxo (membro do IPCC desde 2003), Paulo Guedes está errado porque "[a] maior parte do desmatamento é feita por empresas e pessoas ricas que detêm o poder na região, têm muita influência no Judiciário e no Poder Executivo. Elas simplesmente fazem invasões de terras públicas, e o Ministério Público e a polícia não vão atrás" (Artaxo apud Linder, 2020). Por sua vez, Ricardo Abramovay demonstra que a redução do desmatamento não resulta em redução da produção - o PIB agrícola da Amazônia aumentou cerca de 300\% entre 1999 e 2013, independentemente da redução do desmatamento em aproximadamente $2 / 3$ no mesmo período (2019, p. 38-39). Ainda segundo Abramovay, em 1960 apenas 1\% da floresta amazônica havia sido destruída. Em 2020, sob Bolsonaro, o desmatamento varreu aproximadamente $20 \%$ da floresta tropical $(2019$, p. 34). Abramovay também observa que, em 2016, sob a administração do presidente Michel Temer, o Brasil foi o sétimo maior emissor de gases de efeito estufa (2,278 bilhões de toneladas). Nada menos que $51 \%$ desses gases foram causados pelo desmatamento (Abramovay 2019, p. 32). 0 autor explica que, de acordo com o IPCC da ONU, a diminuição do desmatamento no Brasil entre 2004 e 2012 (administrações dos presidentes Lula e Dilma Rousseff) foi considerada a maior contribuição de um país contra o aquecimento global. A área de desmatamento atingiu 27,7 mil km² em 2004, caindo para 4,4 mil km² oito anos depois. Entre 2003 e 2009, 75\% do aumento em todas as áreas protegidas ao redor do mundo ocorreu no Brasil (Abramovay 2019, p. 17). A partir de 2012, no entanto, o declínio no desmatamento foi revertido. Entre 2015 e 2016, a devastação aumentou 50\% em relação à taxa de 2014. Em 2017, o desmatamento caiu mais uma vez, 16\% em relação a 2016. No entanto, conforme explicado 
por Abramovay (2019, p. 29), apenas em 2017 o desmatamento na Amazônia correspondeu a $6.624 \mathrm{~km}^{2}$, segundo o Observatório do Clima. Vale lembrar que a lei brasileira determina que o desmatamento da Amazônia caia para 3.920 km² em 2020 (Abramovay, 2019, p. 29).

Infelizmente, desde a ascensão de um governo de extrema direita em 2019, todo o progresso e realizações da diplomacia brasileira e das políticas ambientais foram comprometidos. Conforme comentado por Ivo Lesbaupin, "[nos] primeiros meses do governo Jair Bolsonaro, vemos uma total falta de controle por parte das autoridades brasileiras, favorecendo um processo que pode acabar na savanização ou desertificação da Amazônia" (em Abramovay, 2019, p. 8). Em poucos meses, o governo Bolsonaro destruiu uma imagem que havia sido construída ao longo de cerca de 30 anos. Os discursos e políticas públicas de Bolsonaro, todos relacionados ao afrouxamento da vigilância e preservação ambiental, clemência aos agricultores e caçadores ilegais e ódio contra os indígenas e o movimento ambientalista, reposicionaram o Brasil novamente como um dos maiores inimigos do planeta diante da opinião pública internacional. Em matéria publicada no New York Times, Londoño e Casado (2019) informam que a floresta amazônica brasileira perdeu uma área equivalente a cerca de 12 vezes o tamanho da cidade de Nova York entre agosto de 2018 e julho de 2019. Nicolas Bourcier (2019), no Le Monde, analisa "a política incendiária de Bolsonaro na Amazônia": o desmatamento no Brasil aumentou 222\% em agosto de 2019, na relação com o mesmo período em 2018. O Le Monde (2020) informa também que, segundo o Instituto Nacional de Pesquisas Espaciais (INPA) brasileiro, $1.202 \mathrm{~km}^{2}$ de floresta desapareceram entre janeiro e abril de 2020 .

Desde sua posse, Bolsonaro restringiu o poder do IBAMA de inibir e punir o desmatamento e os crimes contra os brasileiros nativos, enquanto queimadas ilegais na floresta tropical e ataques violentos a reservas nacionais, incluindo o assassinato de líderes ambientais e indígenas, marcham em ascensão. Portanto, filmes como Túnel $93^{\circ}$ e Parada 88, realizados na ditadura, parecem ter seu interesse renovado cerca de 50 anos depois, em sua poderosa crítica a um regime que novamente despreza a vida e o meio ambiente.

Quase 30 anos após a redemocratização do Brasil, o imaginário ecodistópico continua alimentando debates sobre o acerto de contas com uma história de autoritarismo e com o aumento da desigualdade favorecida pelo neoliberalismo. Isso pode ser visto em filmes como os já citados Recife frio, Uma história de amor e fúria, ou Branco sai, preto fica - todos 
problematizam o autoritarismo duradouro e uma dívida nunca paga com a maioria dos brasileiros (pretos e pardos) e com os povos indígenas. Conforme todos esses filmes parecem sugerir, a exclusão, a manutenção dos privilégios e a intolerância inviabilizam o desenvolvimento sustentável, arruinam os projetos urbanos e acentuam os danos à natureza. As mazelas sociais resultam em flagelos ambientais, e a insustentabilidade das cidades avança vorazmente para regiões outrora protegidas. Após um breve período de avanços sociais a esse respeito, entre o final dos anos 90 e os anos 2000, o retorno da extrema direita ao poder induz uma revisão de todos os filmes aqui mencionados, pois os alertas que eles veiculam reapresentam-se como válidos e atuais. A ecodistopia parece desaprovar no atacado os governos neoliberais, bem como os regimes pouco democráticos ou autoritários, na mesma medida em que estes sempre desprezaram o ambientalismo. No momento em que estão sendo escritas as páginas finais deste trabalho, a Amazônia e o Pantanal ardem em chamas. 0 governo federal desmantelou todo o esforço ambientalista promovido por gestões anteriores, da modernização do INPE e suas ferramentas de monitoramento à fiscalização do IBAMA. Tal como confessado pelo atual ministro do Meio Ambiente, Ricardo Salles, a pandemia de Covid19 pode ser o momento de se "passar a boiada" no que se refere à desregulamentação.18 Isso significa estímulo ao crime ambiental e à impunidade, ao avanço dos grandes agropecuaristas, madeireiros e mineradores inescrupulosos. Segundo matéria publicada no Jornal da USP (Escobar, 2020),

A destruição da floresta amazônica segue em ritmo acelerado no Brasil. Dados de monitoramento por satélite divulgados nesta sexta, dia 7, [de agosto de 2020] pelo Instituto Nacional de Pesquisas Espaciais (Inpe) mostram que a taxa de desmatamento na Amazônia aumentou 34\% nos últimos 12 meses, em comparação com o mesmo período do ano anterior. É a segunda alta consecutiva nos primeiros dois anos de gestão do presidente Jair Bolsonaro.

\footnotetext{
18 Conforme reunião ministerial gravada, ocorrida em 22 de abril de $2020 \quad($ https://www.youtube.com/watch?v=VkCTwQH55Ic), divulgada publicamente pelo Supremo Tribunal Federal a propósito das investigações do desejo de Bolsonaro em influir na escolha da direção da Polícia Federal do Rio de Janeiro. Assim como as falas do presidente e de demais ministros, as declarações de Salles repercutiram na imprensa, em matérias como a do jornal El País (22 de maio de 2020), que tem como título "Salles vê 'oportunidade com coronavírus para 'passar de boiada' desregulação da proteção ao meio ambiente", e como linha fina: "Comentários do ministro do Meio Ambiente são tradução literal de suas políticas para a preservação, que incluem incentivo a grileiros, desmatadores e madeireiras” (Alessi, 2020).
}

Dossiê 0 Pensamento Ecológico - https://revistaecopos.eco.ufrj.br/

ISSN 2175-8689 - v. 23, n. 2, 2020

DOI: 10.29146/eco-pos.v23i2.27528 
Enquanto os povos indígenas continuam sendo vitimados pela negligência do governo federal, com exposição à Covid-19 e escassez de recursos ou atendimento médico apropriado, a cobiça dos grandes produtores de soja e pecuaristas agora avança também sobre o Pantanal. Antes de tudo isso, Bolsonaro já teria sinalizado sua forma de encarar o meio ambiente quando, por ocasião do Fórum Econômico Mundial de Davos, na Suíça, em 2019, num momento de bastidores, o presidente brasileiro foi procurado pelo ex-vice-presidente dos EUA, o ambientalista Al Gore, que manifesta sua preocupação com a Amazônia. Bolsonaro responde que "A Amazônia não pode ser esquecida. Temos muitas riquezas. E gostaria muito de explorá-la junto com os Estados Unidos”. Atônito, Al Gore replica que não está entendendo muito bem. A explicação apenas acentua o ultraje; o norte-americano desconversa e se despede. A cena, que só recentemente entrou num debate público mais amplo, em virtude da divulgação do filme The forum (2020), de Marcus Vetter, em canais pagos de TV ou serviços de streaming, causou indignação mundial ${ }^{19}$. Toda essa indignação tem provocado reações internacionais, como a campanha \#DefundBolsonaro, que visa a desestimular a compra de produtos brasileiros por cidadãos de outros países até que a política ambiental do governo Bolsonaro se modifique. ${ }^{20}$

O cenário presente realça ainda mais, portanto, a retomada de interesse pela ecodistopia, tendo em vista a sindemia global que agrega, simultaneamente, as epidemias da obesidade, da desnutrição e da mudança climática (Swinburn et al., 2019), somadas à pandemia de COVID-19, a maior crise sanitária global desde o começo do século XX. Ademais, a pandemia de COVID-19, com grande impacto nos modos de conceber e consumir cinema ao redor do mundo, já tem produzido efeitos criativos (e políticos) no Brasil, em filmes como os curtas República (2020), de Grace Passô, ou Missão Perséfone (2020), de Karim Aïnouz, ambos vinculados ao "Programa Convida" do Instituto Moreira Salles.

Em República, obra realizada durante o período de quarentena decorrente da pandemia, Grace Passô interpreta uma personagem que elabora sobre uma inquietante situação de existência refém de uma realidade distópica. 0 curta começa com a personagem de Grace despertando de um sonho. Ela recebe uma chamada no celular, de alguém que lhe passa

\footnotetext{
19 https://www.youtube.com/watch?v=CPpH7FRFcY0

20 https://www.defundbolsonaro.org/. Um vídeo veiculado pela campanha tem tido ampla repercussão nas redes sociais e explica melhor a iniciativa: https://www.youtube.com/watch?v=Y7nMKg3TZrU.
} 
a informação de que o Brasil não existe de fato, de que é apenas o sonho de alguém. Em seguida, visivelmente emocionada, a personagem de Grace abre a janela de seu apartamento e solta um grito em meio à paisagem sonora da cidade. Uma tomada externa em plongée denota a situação de miséria e vulnerabilidade da rua. Do ponto de vista da personagem de Grace, esta parece ver seu duplo gritando na rua. No interior do apartamento, a personagem de Grace liga para sua mãe e pede a ela que ligue a televisão, imediatamente. Ela explica à mãe que "o Brasil é um sonho", que o país não existe, que nenhuma delas existe de verdade, que a casa é um sonho, tudo é um sonho. "Mundo tem, só não tem o Brasil", e "Alguém está sonhando o Brasil", explica a filha. "A qualquer hora a pessoa que está sonhando pode acordar" - e tanto ela quanto sua mãe estariam livres. A distopia é um sonho ruim. Assim como em Branco sai, preto fica, República pode ser visto como outro "grito" eloquente acerca da história da exclusão no Brasil, amplificado sob a lente de um Afrofuturismo cinematográfico brasileiro.

O filme de Karim Aïnouz, por sua vez, começa no ano de 3020, quando a humanidade teria completado 1000 anos de existência num planeta exterior ao Sistema Solar, chamado Superterra. Em 2020, um evento catastrófico teria provocado a extinção da vida animal na Terra e precipitado o êxodo da espécie humana. Intertítulos iniciais explicam melhor a premissa: "A mudança para o novo planeta inaugurou o fim do império da mercadoria e do capitaloceno e o início de uma nova era". Ainda segundo os intertítulos: "A Missão Perséfone é o esforço desta nova civilização, justa e igualitária, de construir uma arqueologia do seu passado no planeta azul, para que os céus nunca mais caiam". Mesclando imagens das mais diversas origens - planos de paisagens, água, terra e ar, tomadas internas e externas, de síntese ou não, além de imagens de arquivo, algumas alteradas digitalmente -, Missão Perséfone ${ }^{21}$ formula um inventário das memórias de nossa existência na Terra, algo parecido a outro curta-metragem brasileiro: Caminhos em busca de um tempo (2001), de Carlos Canela, feito a partir de imagens de arquivo em Super 8. Com uma clara mensagem de conscientização ecológica, o filme de Aïnouz é uma das ecodistopias mais evidentes da filmografia brasileira recente, merecedora de atenção mais detida em ocasião mais oportuna - prova de que esse subgênero resiste, portanto, como uma das manifestações mais estruturadas e longevas no

${ }^{21}$ https://ims.com.br/convida/karim-ainouz/

Dossiê 0 Pensamento Ecológico - https://revistaecopos.eco.ufrj.br/

ISSN 2175-8689 - v. 23, n. 2, 2020

DOI: 10.29146/eco-pos.v23i2.27528 
cinema brasileiro de FC, oferecendo visões críticas e especulativas na encruzilhada das questões sociais, políticas, sanitárias e ambientais.

Talvez mais do que nunca o ambientalismo e os perigos da mudança climática estejam na ordem do dia. Decênios de experimentos e conhecimento científico acumulado, e devidamente validado, têm demonstrado a premência do tema, um avanço comprometido pela ascensão de governos de extrema direita. Paralelamente, os cinemas do mundo (Brasil incluído) têm fornecido algumas das mais provocativas elaborações acerca dos impactos econômicos, sociais, políticos e até mesmo individuais advindos da criminalidade ambiental, do negacionismo ou da simples omissão ou negligência em relação ao bem-estar do planeta. Muitos dos filmes citados aqui indicam que, para além de iniciativas individuais e esporádicas, o problema ambiental precisa ser enfrentado globalmente, como um esforço da espécie humana em sua responsabilidade para com o planeta, sendo impossível salvar o ambiente se não transformarmos profundamente nossa existência econômica - o “capitaloceno" que atualmente nos rege (tal como bem sugerido por Karim Aïnouz). Outro sistema tem de ser possível, por uma simples questão de sobrevivência.

Por tudo isso, as imagens ecodistópicas de nosso cinema não devem ser negligenciadas: são instrumentos valiosos para a conscientização ambiental e lembrete constante de que não existe sociedade justa sem sustentabilidade. 0 colapso ambiental do planeta talvez seja o "evento de extinção" possível sobre o qual mais temos especulado na história da arte - da poesia ao cinema. Por isso encerramos este artigo com a primeira e última estrofes de um poema de Carlos Drummond de Andrade, publicado em 1984 no jornal Cometa Itabirano. 0 poema parece antecipar duas das maiores tragédias ecológicas no Brasil e no mundo: o colapso das barragens de Mariana (em 5 de novembro de 2015, o maior desastre ambiental na área de mineração do mundo) e de Brumadinho (2019), ambas no estado de Minas Gerais eventos que resultaram na morte de pessoas e animais, além de danos irreparáveis ao meio ambiente. Até o presente momento, ninguém foi devidamente responsabilizado e punido (Câmpera 2019). Os versos de Drummond (apud Souza, 2019) soam como um réquiem, um lamento às vidas perdidas e ao crime ambiental cometido.

O Rio? É doce.

A Vale? Amarga.

Dossiê 0 Pensamento Ecológico - https://revistaecopos.eco.ufrj.br/

ISSN 2175-8689 - v. 23, n. 2, 2020

DOI: 10.29146/eco-pos.v23i2.27528 
Ai, antes fosse

Mais leve a carga.

(...)

Quantas toneladas exportamos

De ferro?

Quantas lágrimas disfarçamos

Sem berro?22

Se a realidade não muda, que as imagens dos artistas continuem denunciando o horror.

\section{Referências bibliográficas}

ABRAMOVAY, Ricardo. Amazônia - Por uma Economia do Conhecimento da Natureza. São Paulo: Elefante, 2020.

ALESSI, Gil. "Salles vê 'oportunidade' com coronavírus para 'passar de boiada' desregulação da proteção ao meio ambiente". El País, 22/05/2020, disponível em https://brasil.elpais.com/brasil/2020-05-22/salles-ve-oportunidade-com-coronavirus-para-passarde-boiada-desregulacao-da-protecao-ao-meio-ambiente.html . Acesso em 20/09/2020.

BHABHA, Homi. Nation and Narration. London: Routledge, 1990. O Local da Cultura. Belo Horizonte: Ed. UFMG, 1998.

BOURCIER, Nicolas. "La politique incendiaire de Bolsonaro en Amazonie". Le Monde, 20 de setembro de 2019.

BRANDÃO, Ignácio de Loyola. Não Verás País Nenhum. São Paulo: Círculo do Livro, 1982.

CÂMPERA, Francisco. "Vale, exemplo mundial de incompetência e descaso". El País. 29/01/2019. Disponível em https://brasil.elpais.com/brasil/2019/01/27/opinion/1548547908 087976.html Acesso em 22/09/2020.

CAUSO, Roberto de Sousa. Tupinipunk - Cyberpunk Brasileiro. Papêra Uirandê Especial \# 1: Tupinipunk. São Paulo: edição do autor, 1996, pp. 5-11.

DERY, Mark. Black to the Future: Interviews with Samuel R. Delany, Greg Tate, and Tricia Rose. In: DERY, Mark. Flame Wars: The Discourse of Cyberculture. Durham, Duke Univ. Press, 1994, pp. 179-222.

DUARTE, Lílian C. B. Política Externa e Meio Ambiente. Rio de Janeiro: JZE, 2003.

ELIOT, T. S. A Terra Inútil. Tradução de Paulo Mendes Campos. Rio de Janeiro: Ed. Civilização Brasileira, 1956.

ESCOBAR, Herton. "Desmatamento da Amazônia dispara de novo em 2020". Jornal da USP, 07/08/2020, disponível em https://jornal.usp.br/ciencias/desmatamento-da-amazonia-dispara-denovo-em-2020/. Acesso em 20/09/2020.

22 https://www.unicamp.br/unicamp/ju/noticias/2019/07/16/memorias-poeticas-de-lagrima-lama-e-luta

Dossiê 0 Pensamento Ecológico - https://revistaecopos.eco.ufrj.br/

ISSN $2175-8689-$ v. 23 , n. 2, 2020

DOI: 10.29146/eco-pos.v23i2.27528 
GINWAY, M. Elizabeth. Ficção Científica Brasileira: Mitos culturais e nacionalidade no país do futuro. Sãp Paulo: Devir, 2005.

MOLINA-GAVILÁN, Yolanda; et al. "Chronology of Latin American Science Fiction, 1775-2005". Science Fiction Studies n. 103, vol. 34, parte 3 (novembro 2007): 369-431.

LE MONDE. "Une déforestation inquiétante en Amazonie brésilienne depuis le début de l'année". 9 de maio de 2020.

LINDER, Larissa. "Ricos com influência são os que mais desmatam a Amazônia". Deutsche Welle. Jan 23, 2020. Disponível em https://p.dw.com/p/3WfKR. Accesso em 17/06/2020.

LONDOÑO, Ernesto; CASADO, Letícia. “Amazon Deforestation in Brazil Rose Sharply on Bolsonaro's Watch". The New York Times. 18 de novembro de 2019.

MEADOWS, D.H., et al. The Limits to Growth: a Report for the Club of Rome's Project on the Predicament of Mankind. New York: Universe Books, 1972.

MIRANDA, Luiz F. A. Dicionário de Cineastas Brasileiros. São Paulo: Art Editora, 1990.

ODIN, Roger. A questão do público: uma abordagem semiopragmática. In: RAMOS, Fernão Pessoa. (Org.) Teoria Contemporânea do Cinema (vol.II). São Paulo: Senac, 2005, pp. 27-46.

“Filme documentário, leitura documentarizante". Significação, Ano 39, n 37, 2012, pp. 10-30.

ROCHA, Glauber. "A Estética da Fome”. Milão: s.e., 1965. Disponível na revista Contracampo. Disponível em http://www.contracampo.com.br/21/esteticadafome.htm . Acesso em 18/09/2020.

Revolução do Cinema Novo. São Paulo: Cosac \& Naify, 2004.

SOUZA, Andressa Menezes. "Memórias poéticas de lágrima, lama e luta". Jornal da Unicamp, 16/07/2019. Disponível em: https://www.unicamp.br/unicamp/ju/noticias/2019/07/16/memoriaspoeticas-de-lagrima-lama-e-luta . Acesso em 23/09/2020.

STABLEFORD, Brian. Science Fiction and Ecology. In: SEED, David (ed.), A Companion to Science Fiction. Malden/Oxford/Carlton: Blackwell Publishing Ltd, 2007, pp. 127-141.

SWINBURN, Boyd A., et al. "The Global Syndemic of Obesity, Undernutrition, and Climate Change: The Lancet Commission report". The Lancet. Vol 393, Feb 23, 2019. Disponível em < https://www.thelancet.com/commissions/global-syndemic > Acesso em 16/07/2020.

WOLFE, Gary C. The known and the unknown: the iconography of science fiction. Kent, OH: Kent State University Press, 1979.

\section{Webgrafia:}

TATE. "Afrofuturism". Art-terms. Disponível em https://www.tate.org.uk/art/artterms/a/afrofuturism. Acesso em 20/09/2020.

CINEMATECA BRASILEIRA. Filmografia Brasileira. Disponível em http://cinemateca.org.br/filmografia-brasileira/. Acesso em 17/09/2020.

Dossiê 0 Pensamento Ecológico - https://revistaecopos.eco.ufrj.br/

ISSN $2175-8689-$ v. 23, n. 2, 2020

DOI: 10.29146/eco-pos.v23i2.27528 
CNN BRASIL. "Exclusivo: Regina Duarte minimiza ditadura e interrompe entrevista à CNN". 07/05/2020. Disponível em https://www.youtube.com/watch?v=v9gLHrP7RNw. Acesso em $17 / 09 / 2020$.

DIA, O. "Vídeo: Pazuello diz que inverno do Norte e Nordeste do Brasil é em dezembro e janeiro". 09/06/2020. Disponível em https://odia.ig.com.br/brasil/2020/06/5931266-video-pazuello-dizque-inverno-do-norte-e-nordeste-do-brasil-e-em-dezembro-ejaneiro.html\#: : :text=Rio\%20\%2D\%200\%20ministro\%20interino\%20da,ao\%20inverno\%20do\%20h emisf\%C3\%A9rio\%20Norte\%22. Acesso em 17/09/2020.

PODER 360. "Reunião ministerial de 22 de abril de 2020, na qual Bolsonaro teria indicado interferência na PF". 23/05/2020, disponível em https://www.youtube.com/watch?v=VkCTwQH55Ic. Acesso em 20/09/2020.

PODER 360. Campanha "Defund Bolsonaro" culpa presidente por devastação na Amazônia. 10/09/2020. Disponível em https://www.youtube.com/watch?v=Y7nMKg3TZrU. Acesso em $21 / 09 / 2020$.

PROGRAMA CONVIDA. Instituto Moreira Salles (IMS). Disponível em https://ims.com.br/convida/. Acesso em 17/09/2020.

UOL. "Davos: Bolsonaro diz a Al Gore que 'gostaria muito' de ter EUA como parceiro na Amazônia". 24/082020. Disponível em https://www.youtube.com/watch?v=CPpH7FRFcY0. Acesso em $21 / 09 / 2020$. 